\title{
Development of a Convergence Model for Social Communication of a Philippine Catholic Parish Church
}

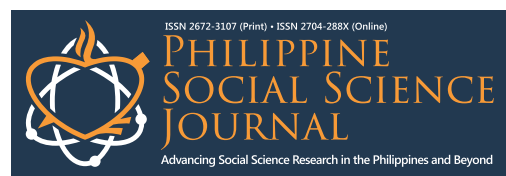

Jonathan V. Gochuico

De la Salle University-Dasmariñas, City of Dasmariñas, Philippines

\section{Article history:}

Submitted: 25 October 2021

Revised: 10 December 2021

Accepted: 21 December 2021

\section{Keywords:}

Development communication

Social communication

Respect for life

Descriptive

Content analysis and survey

Philippines

\begin{abstract}
Social communication is an essential church activity considering the flock's profile and the COVID-19 pandemic. The study determined the convergence and divergence of the parishioners in a Philippine Catholic Church Parish in the City of Dasmariñas, Cavite on Respect for Life, using content analysis and survey methods as bases for the development of a model for social communication. Results revealed that respondents were 31 years-old, female, married, college graduates or attended college, with the parish for 16-30 years, Sunday Churchgoers only, and not members of any Church-based organizations. Parishioners had converging conceptions about the "War on Drugs," extrajudicial killings, and the death penalty even when they could not join Church activities. Parishioners' compliance was acceptable with five convergence points: the sanctity of life, proper appropriation of justice, expression of gratitude for life, healthy living, and understanding the social context of the pronouncements. With this, a social communication model for the Parish Church was recommended, which other parishes may employ.
\end{abstract}

\subsection{Introduction}

The Catholic Church in the Philippines expressed its strong disagreement on the re-imposition of the Death Penalty as the incumbent president, President Rodrigo Duterte, included it in his legislative agenda. On his second state of the nation address on July 24, 2017, President Duterte declared his partiality on capital punishment as part of his war on drugs. In that same speech, the president claimed that. "It is time for us to fulfill our mandate to protect our people. Tapos na 'yan. For so long we have to act decisively on this contentious issue. Capital punishment is not only about deterrence, it's also about retribution" (Official Gazette, 2017).

President Duterte has also expressed his dislike of several Catholic Bishops who openly criticized the Drug War, like Bishop Pablo David of Caloocan, whom he threatened (Esmaquel II, 2019). Also, Bishop David with Archbishop Socrates Buenaventura Villegas of Lingayen-Dagupan, Bishop Honesto Ongtioco of Cubao, and Auxiliary Bishop Teodoro Cruz Bacani Jr of Novaliches were charged with sedition but were eventually dropped by the Department of Justice because of lack of evidence (Torres, 2020). All these were generally perceived as attempts to silence the Catholic clergy.

These events impelled the Catholic clergy to re-examine its Respect for Life Campaign. However, the campaign shifted its focus when law enforcers allegedly did extra-judicial killings to curb the worsening drug problem. Most of these cases came from the urban poor, which led to the public perception that the Drug War was only for the poor. Added to this was a series of pronouncements from the president himself telling police officers to just shoot those who would refuse arrest. According to Human Rights Watch, deaths have already reached around 12,000, but this is countered by the Philippine National Police, stating that only 2,555 could be attributed to the organization. The issue worsened with the death of Kian Loyd Delos Santos and some other individuals who were seen to have surrendered but were still allegedly killed.

How the Respect for Life Campaign can achieve its goal is an essential question that this research endeavor sought to answer. Also noteworthy to investigate are how the Church's conception of Respect for Life is properly communicated and how social communication works so that the value of Respect for Life is communicated to and its practices enhanced among parishioners. As social communication is an important Church activity to teach and promote doctrine and stand on sociopolitical issues, examining strategies and introducing innovation for communication are essential for

This article published by Philippine Social Science Journal (PSSJ) is licensed under a Creative Commons AttributionNoncommercial 4.0 International (CC BY-NC 4.0). You are free to share (copy and redistribute the material in any medium or format) and adapt (remix, transform, and build upon the material). Under the following terms, you must give appropriate credit, provide a link to the license, and indicate if changes were made. You may do so in any reasonable manner, but not in any way that suggests the licensor endorses you or your use. You may not use the material for commercial purposes. 
theorizing wherein communication flow is ontologically top-down and necessitates epistemological and axiological viewpoints. Though the literature is rich with the communication of doctrine and catechism, investigations on the social communication of the Catholic Church as an institution and its parishes are lacking. Papal encyclicals and pastoral letters are available, but understanding and complying with these remain a critical aspect for investigation. Further, it is essential to determine parishioners' construct of Respect for Life to develop frameworks for more effective strategies.

With this context, the socio-cultural dimension of development communication provides a context worthy of investigation as it leads to an understanding and evaluation of theories and learnings applied in authentic settings. Given that notions and actual development work are socially shared, it is necessary to understand how individual constructs of progress are shared and made into collective thought. Fairclough (2010) notes that historical context outlines discursive practices that reveal and expound on the nature of communication. This idea necessitates that theories, perspectives, and perceptions are shaped by the personal understanding of the phenomenon and how these perspectives are communicated and eventually accepted as public opinion.

Underscoring these communication activities is "Inter Mirifica" (On the Means of Social Communication), an apostolic exportation of Pope Paul VI (1963), outlined the purpose and role of social communication in and for the Catholic Church. Upon its promulgation on December 4, 1963, the Catholic Church has called all means of communication, like broadcast, print, cinema, and other similar modes, as "social communication" or "technical inventions" that facilitate the straightforward exchange of information. The Catholic Church believes that these communication modes should be used for clerical activities and promote morality. It is viewed that information is very significant to live decent lives and make principled choices.

This term is distinctive because it encompasses all forms of communication, subsuming all levels in the pronouncement. Inter mirifica declares that bishops should manage social communication that includes "all forms and ways of communicating in human society from traditional forms like storytelling, rumor, drama, dance and music to the Internet and cyberspace" in their respective dioceses. The document recognized the power of communication in shaping public thought and facilitating development initiatives. The purpose and function of communication activities stress the centrality of development communication in the Catholic Church. As Mirus (2010, p. 21) stressed, Inter Mirifica "enjoins upon all Catholics and shows the importance of using social media responsibly, for the common good, and to enhance the apostolic ministry of the [Catholic] Church."

Boshear and Albrecht (1977) stressed that communication builds and keeps relationships that are either converging wherein participants enhance the advantages of the relationship among the participants or diverging wherein the relationship among the participants is discontinued or withdrawn. In this regard, the ego-involvement of participants is essential to keep the communication intact. Attitudes, beliefs, emotions, and even personal views contribute to the continuous harmony of the participants in a communication activity. With these, it is important that communication is consistent and deliberately designed to be personal. Additionally, the participants must be innovative in their communication strategies to continually engage and keep the favorable response of the other.

Communication socialist or social communication was coined to create an expression that encompasses communication among humans and the instruments used in the process (Eilers, 2009). Eilers (2018) provided a historical development of social communication. Films were used as early as 1895 like the passion of Christ, and that studies were done to see the effects of this medium on believers. Published works and research related to the Catholic Church's social communication activities were descriptive or critical. Soukup $(1982,1992)$, as cited in Eilers (2018), observed that studies at that time focused on the following: "issues and approaches, resources, communication theory including theology, Church documents and ethics, media education, history, rhetoric including proclamation and homiletics, orality and writing, interpersonal communication including group and organizational communication, liturgy, mass communication, intercultural communication and other media including also computers." Aside from these, autobiographies of famous Catholic personalities were published like Bishop Fulton Sheen and Pope Saint John Paul II.

Other Catholic Church communicators also broadcast their views and reflections on television and radio, patronizing parishes and religious groups. These communication materials were books, reflections, and guides. Eilers (2018) also cited the works of Dawson et al. (2004), Babin and Zukowski (2002), Campbell (2010, 2012), Campbell and Garner (2016), Cheong et al. (2012) as they examined 
the Catholic Church's use of the internet, and that of Buddenbaum and Mitchell (1998), Mitchell and Marriage (2003), Baderacco (2005), Hoover (2006), Geybels (2007), and Stout (2012) as cyberspace is viewed as a developing field.

The investigation determined the socio-demographic and Church-related profile of the parishioners in a Philippine Catholic Church Parish in the City of Dasmariñas, established the parishioners' constructs of Respect for Life", and proposed a social communication framework for the parish.

\subsection{Framework of the Study}

The research is anchored on Communication for Compliance Gaining, where Berger (2015) posited that communication inherently aspires for 'social goals' that demand careful preparation and development. In this perspective, the communication process is ordered and follows a scheme to ensure the accomplishment of desired goals. Central in this theory is concentrating on making sense of communication as goal-directed action. That discourse directs individuals towards sharing these goals with the communicator. According to Marwell and Schmitt (1967, as cited in Roloff, 1994), compliance gaining is an aspect of communication wherein communicators actively shape messages to gain accordance and conformity. The theory notes that all communication processes persuade people to accept certain perspectives and discourse content. Also, it underscores the communicator's inherent power, and at times authority, as approaches are reserved to them. It is presupposed that compliance is assured by carefully crafting messages, and its manifestations are observed through favorable actions and public opinion or are extended in other communicative acts. Compliance is a significant goal of communication activities which necessitates a thorough understanding of communication elements leading to the importance of the proposed communication model.

\subsection{Methods}

The descriptive research design was used to trace and describe the pronouncements of $C B C P$, specifically on "War on Drugs", extrajudicial killings (EJK), and the death penalty for drug-related crimes. Content analysis was done as a core method using NVIVO. A survey was also conducted to establish parishioners' constructs and their convergence with religious and socio-political beliefs. The development of a convergence model for social communication was created based on the results.

The researcher-made survey was validated with a Cronbach alpha of 0.896, deemed with a high level of consistency, and was further endorsed by a panel of examiners from the University of the Philippines Los Baños. This determined the socio-demographic and church-related profile of the parishioners and their agreement or disagreement with the pastoral letters was established through mean scores and interpreted as highly acceptable (4.50-5.00), Acceptable (3.50-4.49), Moderately acceptable (2.50-3.49), Fairly acceptable (1.50-2.49), and Not acceptable (1.00-1.49).

Sixty-five Pastoral Letters were released from 2016 to 2019. These were delineated to 15 or those only related to Respect for Life, culled through CBCP's official website. Descriptive coding was done to initially determine recurring codes and themes to establish initial codes and arrive at initial labels. Second cycle coding was done through pattern coding to further ascertain categories. These coding cycles allowed for the determination of key concepts for a convergence model for social communication.

Meanwhile, the research locale is a Catholic parish church in the City of Dasmariñas, Cavite, which has a population of 17,134 based on the 2015 Census. The sample size was 393 computed using Slovin's formula with a 0.5 margin of error. The criteria were: (1) at least 15 to 18 years old given the nature of the topic and (2) willing to participate.

The Parish Priest was interviewed to give insights on the communication activities of the parish and clarify survey results. A priest from the Society of Saint Paul, a social communication expert, was also interviewed to gain insights into the communication activities of the Catholic Church. Interviews were also conducted with a youth leader, a catechist, a parochial school teacher, a professional, and an elder through the coordination of the parish priest since the chaplain wanted that health protocols were observed during the interviews.

For ethical considerations, approval and endorsements from the Bishop of the Diocese of Imus and the Parish Priest of the research locale were constantly sought. Approval from the Ethics Review Committee of De La Salle University - Dasmariñas was also sought. The researcher declares that 
there is no conflict of interest. He is a member of the Roman Catholic faith but he is not within the jurisdiction of the Parish.

\subsection{Results}

\section{Profile of Respondents}

The socio-demographic profile of the respondents noted that females were more involved in church-based activities, with a mean age of 32. Most of the respondents were married and had reached or finished tertiary education. The respondents' profile is presented below:

Table 1. Respondents' socio-demographic profile

\begin{tabular}{|c|c|c|}
\hline Category & $f(n=393)$ & $\%$ \\
\hline \multicolumn{3}{|l|}{ Age } \\
\hline 18-24 years old (Early working age) & 150 & 38 \\
\hline 25-54 years old (Prime working age) & 216 & 55 \\
\hline $55-64$ years old (Mature working age) & 16 & 4 \\
\hline 65 years old and over (Elderly) & 11 & 3 \\
\hline \multicolumn{3}{|l|}{ Age Range = $18-81$} \\
\hline \multicolumn{3}{|l|}{ Age Mean $=31.91$ or 32} \\
\hline \multicolumn{3}{|l|}{ Gender } \\
\hline Female & 220 & 56 \\
\hline Male & 173 & 44 \\
\hline \multicolumn{3}{|l|}{ Civil Status } \\
\hline Married & 214 & 54 \\
\hline Single & 164 & 42 \\
\hline Widow/ Widower & 11 & 3 \\
\hline Separated & 4 & 1 \\
\hline \multicolumn{3}{|l|}{ Educational Attainment } \\
\hline College Level & 267 & 68 \\
\hline High School Level & 87 & 22 \\
\hline Elementary Level & 6 & 2 \\
\hline No formal schooling & 33 & 8 \\
\hline \multicolumn{3}{|l|}{ Occupation } \\
\hline \multicolumn{3}{|l|}{ Employed } \\
\hline Support Service workers & 88 & 22 \\
\hline Elementary Occupations & 79 & 20 \\
\hline Professionals & 34 & 9 \\
\hline Technical\& associate professionals & 16 & 4 \\
\hline Craft and related trade workers & 16 & 4 \\
\hline Unemployed & 116 & 30 \\
\hline Student & 33 & 8 \\
\hline Church-related & 25 & 6 \\
\hline
\end{tabular}

The socio-demographic profile confirmed the PSA 2015 data of Cavite. It coincides with the findings of a demographic study by Pew Research Center (2016) wherein females were known to have more active engagements in Church-based activities. The same study associated minimal attendance of males in religious activities because of testosterone "marking a great genetic difference between the sexes."

Meanwhile, respondents' civil status reflected the Cavite Ecological Profile 2017. More so, the educational attainment agreed with the study by Initiative on Faith and Public Life (2015), noting that Church attendance and academic achievement were highly correlated. 
Regarding the respondents' occupation, the majority were call center agents, waiters, technicians, security guards, and sales clerks. This was followed by factory workers, promodisers, kargador, construction workers/ laborers, launderers, and fast food crew. The respondents were reporting to work even during Sundays, which affected their Church attendance. Thirty percent of the respondents were unemployed, which could have been caused by the COVID19 pandemic, which has affected the locale at the time of data gathering.

The respondents' church-related profile was also established. This is presented in Table 2.

Table 2. Respondents' Church-related profile

\begin{tabular}{lcc}
\hline \multicolumn{1}{c}{ Category } & $f(n=393)$ & $\%$ \\
\hline Length of Stay in the Parish & & \\
15 years and below & 116 & 30 \\
16-30 years & 22 & 57 \\
$31-45$ years & 49 & 21 \\
46 years and more & 4 & 1 \\
Frequency of Church & & \\
attendance & 360 & 91 \\
Sundays only & 31 & 8 \\
1 to 3 times a week & 2 & 1 \\
4 to 7 times a week & & \\
Membership in a Church- & & 23 \\
based organization & 90 & 77 \\
Member & 303 & \\
Non-member & & \\
\hline
\end{tabular}

As regards the Parishioner's Church- related Profile, 70\% had stayed for more than fifteen years. The Parish Priest affirmed that the sacramental needs of these parishioners were administered by the parish but may still have limited involvement since almost all attended Mass during Sundays only. With this profile, the communication expert substantiated the need to make materials that will impact the Church's stand about Respect for Life outside the mass and make these materials available even beyond the church's vicinity.

Of the 393 parishioners surveyed, only 90 joined groups and organizations as collaborators during the Holy Mass or as communities of prayer and faith. This has happened because parishioners were either working or resting during Sundays and that parishioners were not obligated to join or be active in Church-based organizations and activities. Further, only eleven respondents had multiple memberships in Church-based organizations either as a lector, commentator, or choir; or joined organizations that function and serve outside the Mass. It was also observed that those with multiple memberships were single, 18 to 24 years old, and were young professionals.

As regards the involvement of those who were members of organizations, most parishioners were plain members (57), mass servers (12), or catechists (3) who had leadership roles. Only ten members had direct participation in Church-based activities either as Officers (8) or as coordinators (2). This result noted that most of those active in Church-based organizations did not have direct involvement in the creation and were recipients of communication materials. Further, the Parish Priest underscored the challenge of developing programs and initiating activities that will entice more parishioners to join Church-based activities.

Church-related profile was limited to what has been gathered since such profile was fluid and may not be confirmed with parish data. The parish priest noted that profiling in the parish was limited to membership in church-based organizations, membership in Bukluran, or the basic ecclesial community, which is composed of five families per Bukluran sacramental records. The parish may also access students' profiles from the parochial school.

The need to put up a mechanism to develop and document parishioners' profiles as reflected in Sembrano (2014) despite the challenges in resources and the limitation brought by the COVID-19 pandemic. Effective profiling will also further popularization and marketing strategies that may lead to compliance and convergence with Church pronouncements as stipulated by Gawronski and Majkowska (2018) and Mapuweyi and Wozniak (2018). 


\section{Constructs of Respect for Life in CBCPs Pronouncements}

Respect for life has been a recurring theme in the Pastoral Letters and pronouncements of CBCP. In this study, the pastoral letters were contextualized on the pronouncements made by the current president and implemented policies like "War on Drugs" and "Oplan Tokhang," among others wherein CBCP's Respect for Life went in direct opposition to the government. "War on Drugs" was criticized as a form of extrajudicial killing.

The construct "Protecting the sanctity of life" was rooted in the doctrine that life comes and is a gift from God. Related categories of these concepts were the very slogan of the campaign, which was "Huwag kang papatay!" (Thou shall not kill); Life is sacred; and "War on Drugs" is bloody and must be stopped. These categories pointed out that life should be valued - even the lives of drug addicts and criminals.

Another construct was "calling for social justice", which was drawn from the following statements from the Pastoral Letters: (1) Restoration, not retribution; (2) War on Drugs" killed innocent civilians and even the clergy.; (3) EJK promotes a culture of violence.; (4) Conversion for all.; (5) Death penalty is not an effective deterrent against crimes.; (6) Capital punishment and a flawed legal system is a lethal mix.; and (7) The opportunity to change is never lost in every person. This concept stressed the notion that the government's efforts failed in achieving justice.

"Promoting the common good" as another construct was drawn from the following pastoral letter statements: (1) We could not give up on anyone; (2) Healing for the addicted. "War on Drugs" is "anti-poor"; (3) The drug problem is caused by poverty of the majority, the destruction of the family, and corruption in society.; (4) The drug problem is caused by poverty of the majority, the destruction of the family, and corruption in society.; and (5) Social media should promote what is true, what is just, and what is for the common good. These concepts were based on the basic teachings of the Catholic Church.

\section{Parishioners' Respect for Life Constructs}

Looking at the respondents' constructs of Respect for Life, $72 \%$ or 282 respondents considered life a gift from God. In comparison, $19 \%$ or 75 respondents noted that life must be respected. The majority of the respondents upheld the sanctity of life that should be protected and defended.

Forty-seven percent were aware of CBCP's stand on "War on Drugs" because not all homilies focused on Respect for Life, as the Parish Priest confirmed. At the same time, the non-obligatory stance of the Parish as regards activities might have contributed to this number.

Of the 393 respondents, 186 were aware of CBCP's stand against the "War on Drugs". With this result, $69 \%$ or 101 respondents negatively view the government's campaign. Details of this finding are presented in the table below:

\begin{tabular}{lll} 
Table 3. Views on "War on Drugs" & \\
\hline Views & $\mathrm{f}$ & $\%$ \\
\hline & & \\
"War on Drugs" is about killings. & 65 & 35 \\
"War on Drugs" is against CBCP & 30 & 16 \\
"War on Drugs" causes social conflicts. & 4 & 2 \\
"War on Drugs" is totally wrong. & 1 & 1 \\
"War on Drugs" is anti-poor. & 1 & 1 \\
\hline
\end{tabular}

On the other hand, the $31 \%$ who regarded "War on Drugs" positively still attributed this perception to the Catholic Church's influence and not to the government. They viewed that the campaign was aligned with CBCP's values of life (19\%) and that bishops support the "War on Drugs" (12\%).

There was consistency regarding respondents' awareness of extrajudicial killings associated with the "War on Drugs" since 55\% (216 respondents) were unaware of CBCP's stand about it. The $45 \%$ (177 respondents) who were aware of the EJK, unfortunately, were not actively involved in Churchbased activities against it because of livelihood and economic-related activities. It may be deduced that there was a need to inform the parishioners more about CBCP's stand on extrajudicial killings and that communication strategies must be improved and other communication materials be created. 
With the 393 respondents, 175 were aware of CBCPs stand and viewed extrajudicial killings unfavorably, thereby expressing converging notions with $C B C P$. The respondents said that most victims of EJK were deprived of the opportunity to mend their ways and that most come from economically disadvantaged sectors. Respondents' views are presented below:

Table 4. Views on Extrajudicial Killings

\begin{tabular}{lll}
\hline Views & $\mathrm{f}$ & $\%$ \\
\hline EJK is a defiance of Church doctrines & 100 & 57.0 \\
EJK is a social justice and human rights issue. & 72 & 41.0 \\
EJK is a safety concern. & 3 & 2.0 \\
\hline
\end{tabular}

The respondents noted that they fear being falsely accused and being at the receiving end of EJK. It can be viewed that more than half saw EJK as a religious issue while the other half viewed it as a political concern. This may explain why only a few get involved in Church-based and Church-initiated activities looking at the divide on what the Church should focus on.

Of the 393 respondents, $47 \%$ or 185 respondents were aware of CBCPs stand have unfavorable concepts of the Death Penalty. This may be attributed to the contents of Pastoral Letters. The converging concept of the Death Penalty is triggered by its opposition to Catholic Church doctrines. Fifty-two respondents noted that $C B C P$ disapproved of capital punishment. One hundred twenty-one respondents raised issues like social injustice, preservation of human life, and opportunity to change as reasons for disproving the Death Penalty. Only one respondent was uncertain, and $11 \mathrm{did}$ not indicate their answers.

Due to the generally low level of awareness of the "War on Drugs", EJK, and death penalty among the parishioners, only a handful were able to join church-initiated activities related to these issues and in its Respect for Life Campaign. These activities included "Walk for Life" and similar mobilizations, prayer rallies and ecumenical drug force, online forums, seminars, and retreat and recollection. It was noted that much information and activities where the respondents were involved were limited solely to those held during the Holy Mass.

Parishioners did not take an active stance as regards Respect for Life across the three different issues related to the campaign. A great majority of the respondents had not attended any Churchbased activity. Moreover, the parishioners opted to be silent on their non-involvement with activities related to the "War on Drugs," which is a controversial and even dangerous topic to some because there were individuals who were apprehended because of allegations of drug pushing. In an interview, one participant revealed that drug activities were extensive in the locale. Many were apprehended without due process as they enlisted their names in "Oplan Tokhang" instead of being given amnesty, which they hoped for. Worse was that many were also eventually shot down or killed for allegedly fighting it out with the police. The silence of the respondents on this aspect revealed that such fear may still be prevalent when the study was conducted.

With all these, the findings of the study noted that there is a need to start activities that will allow further male engagement while sustaining female engagement. Further, there is a need to develop mechanisms that would gather demographic information of the parishioners to develop different communication materials for different sectors of the parish.

Aside from this, the findings furthered insights on the relative effectiveness of the communication strategies and activities of the Parish. This also seemed to explain the favorable perception of the "War in Drugs" despite the disagreement of the Catholic clergy. It may be surmised that messages effectively created a negative impression of the government's stand among those who have heard about the campaign. This emphasizes the significance and role of the Holy Mass in communicating critical aspects of the Respect for Life Campaign and further communication activities that will convey its stand using other communication strategies.

\section{Proposed Social Communication Framework for Respect for Life}

This study determined that the socio-demographic and church-related profiles of the respondents, constructs of Respect for life-based on the communication materials of $C B C P$, parishioners' awareness of CBCP's Respect for Life Campaign, and communication strategies employed by the Catholic Parish Church in the City of Dasmariñas are substantially connected to parishioners' convergence or divergence and compliance to the Campaign. In the proposed framework, social communication 
was viewed as an integral process in the parish as church doctrines, and teachings contextualized in CBCP's pastoral letters were conveyed and publicized.

The Parish should consider developments in people and institutional sources to enhance communication strategies and make communication materials. As the parish priest was recognized as the leader and expert in Respect for life, he should also explore processes that will empower leaders and members of church-based organizations since the number of parishioners was relatively large. Mechanisms should also be in place to sanction and hone laypersons who may help in the social communication of the parish.

"Huwag kang papatay" was an effective catchphrase that should be maintained as this was already familiar to the parishioners and was an effective springboard to issues related to Respect for Life. While a significant number were unaware of the campaign and were indifferent to joining church-initiated activities, approaches using social media and undertakings not requiring physical presence in the church vicinity should be explored. Social media, in this regard, maybe maximized as the majority of the parishioners have access to the internet and prefer this type of mode.

It may be inferred that the communication strategies of the parish relied heavily on face-toface communication as evidenced by group meetings, conversations among parishioners through Bukluran, and home visits. Although it was recognized that some communication materials were also used for the general public, like tarpaulins and posts on the official Facebook page, more encompassing strategies should also be explored as the current pandemic has affected and prohibited these activities like street masses and theatrical presentations.

The proposed social communication framework recognized the centrality of the parish priest, the varied involvement of parishioners, and the nature of communication that must be done, given that some parishioners were actively immersed while some were only hearing masses every Sunday. The framework identified three types of parishioners as determined by the study, wherein the first type encompasses communication activities within the church structure that is readily available to those who are actively engaged in Church-based activities. The term for this type is Bukluran because communication effort is minimal and may concentrate on face-to-face, dialogic schemes. Parishioners may directly refer to the parish priest for deepening concepts related to Respect for life. The parish priest also develops communication activities to empower leaders of church-based organizations who may help the parish in explaining such concepts to other stakeholders.

Regular Churchgoer is the second type wherein social communication is for those who go to church every Sunday and have access to other communication materials like bulletin boards or tarpaulins posted within the church's vicinity. They may also hear homilies, but the information they get is limited since their involvement is also limited. They view that attending Sunday mass is the only obligation they need to fulfill, and they may have other activities and obligations on Sundays, which may limit or hamper their attendance in Church-based activities. Still, it is much easier to communicate Respect for Life since they regularly go to Church and may be exposed to other communication materials like drama and poetry, theatrical presentations, and IEC materials which must be done during the mass. Further discussions at this level may be facilitated by leaders or members of Church-based organizations.

Seasonal and Nominal is the third type wherein communication activities are for those who rarely go to church or have inconsistent church attendance. They may also be those who are uninterested in church-based activities and may require more exposure to mediated content focusing on Respect for life. Parishioners under this category may require more encompassing, more accessible, and more easily understood communication materials. The Bukluran group may also conduct visitations to reach out to this group so that it is more personal and community-based. Such social communication activities and strategies are deemed as less intimidating and maybe less "churchy," which could be a good springboard to start, build, and eventually maintain convergence.

This group may also be approached by Church-based organizations through group activities like prayer or bible studies, fellowships, and mobilizations. These activities may communicate expositions about Respect for life and may entice this group to be more actively involved in Church activities by deconstructing the notion that activities and events are "pang taong simbahan lang".

The Parish should target these groups through broadcast and social media and attract or persuade them to at least hear mass regularly so that they get to listen to expositions on Respect for Life. These materials should motivate these parishioners to further their understanding of issues about Respect for life and lead them to interact with either laypersons or the parish priest. The Parish 
may also explore the distribution of IEC materials or the use of tarpaulins to reach out to this group.

The proposed model is relevant to the pandemic, which has affected the conduct of the study and may have influenced the perspectives of both the Parish and its parishioners. Going to the parish and observing all religious activities were temporarily prohibited from stopping the spread of the virus. Thus, face-to-face communication and all materials used within the vicinity of the parish like tarpaulins, bulletin boards, and IECs were not possible. Mediated content is the only mode possible for social communication. The Parish may explore broadcasts like television and radio. Since resources are limited, it may explore partnerships with institutions like De La Salle University - Dasmarinas for radio which is just within the locale. It may also maximize the use of social media, like Facebook and Youtube, not just to stream online masses but produce shows that will explain Respect for Life and other Catholic Church doctrines.

One crucial consideration is looking at the parishioners as a single group that will access mediated content. Though it may be assumed that no difficulty will be encountered with the Bukluran group to encourage them to access messages from the parish, connectivity may be a concern; and that those classified as regular church-goers or seasonal and nominal may have a more stable internet connection. As such, the parish must be able to convince all parishioners to access online content.

Another critical element is developing mechanisms that will promote effective feedback processes to see points of convergence and divergence. The parish should be able to create strategies that will assure convergence and successfully address diverging points to further compliance. Since communication is indirect and lacks the necessary dialogic process, the parish priest, deemed as the authority on the topic, should explore mechanisms to make the process more interactive, being an inherent attribute of social media. This will further engagement among parishioners.

A visual presentation of this framework is presented below:

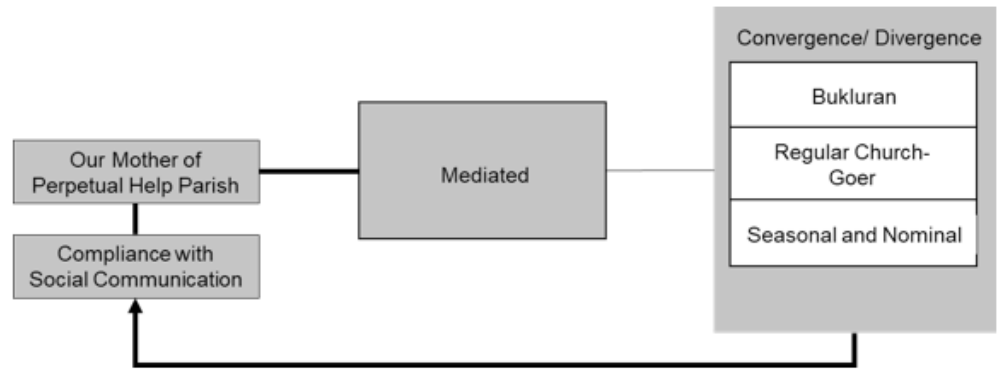

Figure 1. Proposed Convergence Model for Social Communication for Pandemic

\subsection{Conclusion}

In conclusion, parishioners are 31 years old, female, college graduates, and employed in the support service sector. They have been in the parish for 16 to 30 years, hear mass during Sundays only, and are not members of any church-based organization. The constructs derived from CBCP's Pastoral Letter are protecting the sanctity of life, calling for social justice, and promoting the common good. The majority considered life as a gift from God. Parishioners associate the "War on Drugs" with killings. They are aware of CBCP's stand against extrajudicial killings and the death penalty and have negative constructs of them. Most of them are not able to join Church-based activities related to Respect for Life because of being busy or not aware of the activity.

There is a need to further establish the demographic profile of parishioners across parishes to determine appropriate communication activities and strategies. This implies the active determination of appropriate and effective communication strategies and platforms for Church-based advocacies like Respect for Life. Other aspects like political, economic, and educational contexts may be examined as well to see how development communication, politics, and religion are corollary concepts. As part of theory construction, the proposed model may be validated to streamline communication approaches and activities that ascertain convergence and even explain and anticipate divergence. 


\section{REFERENCES}

Berger, C. R. (2015). Communication failure/miscommunication. The International Encyclopedia of Interpersonal Communication, 1-11. https://doi.org/10.1002/9781118540190.wbeic233

Boshear, W. C., \& Albrecht, K. (1977). Understanding people, models, and concepts. University Associates.

Eilers, F. J. (2009). Church and social communication. Faith and Media: Analysis of Faith and Media: Representation and Communication, 17, 39.

Eilers, F. (2018). Religion and social communication in Asia: Towards a research agenda. Journal of the Asian Research Center for Religion and Social Communication, 16(1), 3-18. https://www.asianresearchcenter.org/ arc-journal

Esmaquel II, P. (2019). Duterte said kill the bishops - and his word became flesh. Rappler. https:// www.rappler. com/newsbreak/in-depth/duterte-word-became-flesh-kill-bishops

Fairclough, N. (2010). Critical discourse analysis: The critical study of language. $2^{\text {nd }}$ Ed. London, United Kingdom: Pearson Education ESL. https://www.felsemiotica.com/descargas/Fairclough-Norman-Critical-DiscourseAnalysis.-The-Critical-Study-of-Language.pdf

Gawroński, S., \& Majkowska, I. (2018). Marketing communication of the Catholic Church: A sign of the times or profanation of the sacred. Studia Humana, 7(2), 15-23. https://doi.org/10.2478/sh-2018-0007

Mapuweyi, N., \& Wozniak, J. (2018). Discourses of power and counter-power in the Zimbabwean politicoreligious communication in online news media. Journal of African Media Studies, 10(3), 273-295. https://doi. org/10.1386/jams.10.3.273_1

Mirus, J. (2010). Vatican I/ on social communication. Catholic Culture https://www.catholicculture.org/commentary/ otc.cfm?id=597.

Official Gazette. (2017). Rodrigo Roa Duterte's second state of the nation address. https://www.officialgazette.gov. $\mathrm{ph} / 2017 / 07 / 24 /$ rodrigo-roa-duterte-second-state-of-the-nation-address-july-24-2017.

Paul, VI. (1963). Inter Mirifica. Decree on the media of social communications. https://www.vatican.va/archive/ hist_councils/ii_vatican_council/documents/vat-ii_decree_19631204_inter-mirifica_en.html

Pew Research Center. (2016). The gender gap in religion around the world. https://www.pewforum. org/2016/03/22/the-gender-gap-in-religion-around-the-world

Roloff, M. E. (1994). Validity assessments of compliance gaining exemplars. Communication Theory, 4(1), 69-81.

Sembrano, E. (2019, September 23). Latter-day Saints church turns over four centuries of digitized Catholic records to $C B C P$. https://lifestyle.inquirer.net/346381/mormons-turn-over-4-centuries-of-digitized-philippinecatholic-records-to-cbcp/

Torres, J. (2020). Prosecutors drop sedition charges against Philippine bishops. Union of Catholic Asian News. https://www.ucanews.com/news/prosecutors-drop-sedition-charges-against-philippine-bishops/87196

\section{Correspondence:}

JONATHAN V. GOCHUICO

jvgochuico@dlsud.edu.ph

https://orcid.org/0000-0003-0160-2794 